\title{
Carbon Dioxide Exchange Between an Old-growth Forest and the Atmosphere
}

\author{
Kyaw Tha Paw U, ${ }^{1 *}$ Matthias Falk, ${ }^{1}$ Thomas H. Suchanek, ${ }^{2}$ \\ Susan L. Ustin, ${ }^{1,3}$ Jiquan Chen, ${ }^{4}$ Young-San Park,${ }^{1}$ \\ William E. Winner, ${ }^{5}$ Sean C. Thomas, ${ }^{6}$ Theodore C. Hsiao, ${ }^{1}$ \\ Roger H. Shaw, ${ }^{1}$ and Thomas S. King, ${ }^{1,7 \dagger}$ R. David Pyles, ${ }^{1}$ \\ Matt Schroeder, ${ }^{1}$ and Anthony A. Matista ${ }^{1}$
}

\begin{abstract}
${ }^{1}$ Department of Land, Air and Water Resources, University of California, Davis, California 95616, USA; ${ }^{2}$ Department of Environmental Contaminants-W-2605, US Fish and Wildlife Service, Sacramento, California 95825, USA; ${ }^{3}$ Western Regional Center: National Institute for Global Environmental Change, University of California, Davis, California 95616, USA; ${ }^{4}$ School of Landscape Ecology and Ecosystem Science (LEES), Earth, Ecological and Environmental Sciences (EEES), Bowman-Oddy Laboratories, University of Toledo, Toledo, Ohio 43606-3390, USA; ${ }^{5}$ Department of Botany and Plant Pathology, Oregon State University, Corvallis, Oregon 97331, USA; ${ }^{6}$ Faculty of Forestry, University of Toronto, Ontario, M5S 3B3 Toronto, Canada; ${ }^{7}$ College of Forest Resources, University of Washington, Seattle, Washington 98195, USA
\end{abstract}

\begin{abstract}
Eddy-covariance and biometeorological methods show significant net annual carbon uptake in an old-growth Douglas-fir forest in southwestern Washington, USA. These results contrast with previous assumptions that old-growth forest ecosystems are in carbon equilibrium. The basis for differences between conventional biomass-based carbon sequestration estimates and the biometeorologic estimates are discussed. Annual net ecosystem exchange was comparable to younger ecosystems at the same latitude, as quantified in the Ameriflux program. Net ecosystem carbon uptake was significantly correlated with photosynthetically active radiation and air temperature, as well as soil moisture and precipitation. Optimum ecosystem photosynthesis occurred at relatively cool temperatures $\left(5^{\circ}-10^{\circ} \mathrm{C}\right)$. Understory and soil carbon exchange always represented a source of carbon to the atmosphere, with a strong seasonal cycle in source strength. Understory and soil carbon
\end{abstract}

exchange showed a $Q_{10}$ temperature dependence and represented a substantial portion of the ecosystem carbon budget. The period of main carbon uptake and the period of soil and ecosystem respiration are out of phase, however, and driven by different climatic boundary conditions. The period of strongest ecosystem carbon uptake coincides with the lowest observed values of soil and ecosystem respiration. Despite the substantial contribution of soil, the overall strength of the photosynthetic sink resulted in the net annual uptake. The net uptake estimates here included two correction methods, one for advection and the other for low levels of turbulence.

Key words: net ecosystem exchange (NEE); gross ecosystem production; eddy covariance; biometeorology; old-growth forest; carbon flux; carbon dioxide; Wind River Canopy Crane.
Received 15 February 2002; accepted 20 May 2003; published online 19 May 2004.

*Corresponding author; e-mail: ktpawu@ucdavis.edu

${ }^{\dagger}$ Present address: Goddard Space Flight Center, Data Assimilation Office, Greenbelt, Maryland, 20771, USA

\section{INTRODUCTION}

Despite controversy about the location of a carbon (C) sink, there is an emerging consensus about the 
existence of a terrestrial carbon sink of 1-2 Pg carbon per year in the Northern Hemisphere (Pacala and others 2001). Several mechanisms have been suggested to account for this sink, in particular forest regrowth, especially reforestation in the eastern United States have been suggested (Schimel 1995; Goulden and others 1996; Fan and others 1998; Battle and others 2000; Schimel and others 2000). The role of old-growth forests in sequestering carbon has not been explored, and it has been generally assumed that these forests represent carbon sources or are neutral (Odum 1963, 1965; Melillo and others 1996). Recently Carey and colleagues (2001) found a potentially significant carbon sink in old forests in the Rocky Mountains. Detailed measurements of the exchange of carbon dioxide $\left(\mathrm{CO}_{2}\right)$ between vegetation and the atmosphere are needed to understand the role of various forest ecosystems in the global carbon budget.

A number of articles published in the past 15 years have suggested that old-growth conifer forests are at equilibrium with respect to net ecosystem productivity (NEP) or net ecosystem exchange (NEE) (DeBell and Franklin 1987; Franklin and DeBell 1988; Schulze and others 1999), as an age-class end point of ecosystem development. Related to this concept is the view that young forests represent some of the most significant sinks of $\mathrm{CO}_{2}$ because of their rapid growth (Houghton and others 1983; Birdsey and others 1993; Heath and Birdsey 1993; Wofsy and others 1993; Turner and others 1995; Schimel and others 1996: 78; DeLucia and others 1999). Janish and Harmon (2002) examined carbon stores in the Wind River watershed and found maximum carbon accumulation in forests of the 200-year age class. Respiration in young stands released more carbon because of legacies from prior forests. Goodale and colleagues (2002), using inventory data of temperate and boreal forests and models, concluded that over $80 \%$ of the estimated terrestrial sink occurred in just one-third of the forest area, in temperate regions affected by fire suppression, agricultural abandonment, and plantation forestry, implying that regrowth was a significant factor in forest carbon sequestration. These studies have been mainly based on aboveground biomass estimates derived from biometry and other inventory methods. It is generally assumed that forests reach maximum productivity at an intermediate age and productivity declines in mature and old-growth stands (Franklin 1988), presumably as dead woody debris and other respiratory demands increase. Douglas-fir-western hemlock forests reach a transition point between density-dependent mortality (thinning) due to competitive exclusion and density-independent mortality (due to insects, disease, and windthrow) between 80 and 250 years, when woody debris accumulates and crown gaps begin to be created (Franklin and others 2002). Presumably, the increasing respiratory costs largely account for declining productivity. Maturity-related declines in forest productivity are relevant to planning mitigation strategies (Banuri and others 2001).

Other biometric and inventory studies have reported that older forests may have substantial sink activities (Grier and Logan 1977; Turner and others 2000). The difficulty in determining source and sink relationships in such studies partially stems from the large number of processes that must be inventoried, including significant belowground processes that may be major fractions of the total NEE and NEP (Ehman and others 2002; Malhi and others 1999; Schulze and others 1999).

One way to estimate NEE independently is to use micrometeorologic methods (Malhi and others 1999; Post and others 1999). Although traditionally these methods have been confined to idealized locations with flat terrain and uniform vegetation cover over large areas, they have been extended to much less ideal ecosystems (nonflat terrain, heterogeneous ecosystems) in the past decade (Wofsy and others 1993; Goulden and others 1996; Baldocchi and others 2000; Valentini and others 2000; Paw U and others 2000). Eddy covariance involves the fewest assumptions of any of the micrometeorologic techniques. In this method, high-fre quency data from scalars, such as the $\mathrm{CO}_{2}$ concentration, are multiplied, point by point, with corresponding high-frequency data of the vertical wind velocity, to obtain the vertical exchange of the scalar. Some caution must be used, in estimating NEE from eddy flux, as described by Lee (1998) and Paw U and colleagues (2000), and as described in the methods section.

In this report, we describe the estimation of $\mathrm{CO}_{2}$ exchange from the oldest forest ecosystem ( 500 years old) in the AmeriFlux network, based on eddy covariance, using accepted AmeriFlux correction techniques for low friction velocities and turbulence levels, and related advection calculation methods. We examine the $\mathrm{CO}_{2}$ exchange response to diurnal, seasonal, annual, and interannual variations, and relate the exchange to meteorologic variables such as photosynthetically active radiation (PAR) and soil and air temperatures. Harmon and colleagues (2004) estimate NEE from inventory methods, and Winner and coworkers (2004) from scaling photosynthesis measurements. Relationships between environmental variables and 


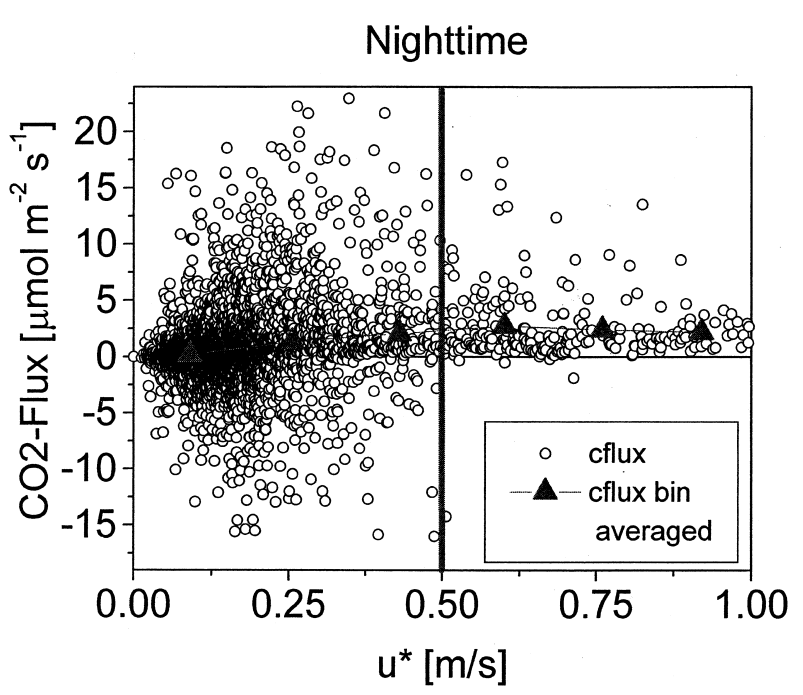

Figure 1. Nighttime half-hour $70 \mathrm{~m}$ eddy-covariance as a function of friction velocity $\mathrm{u}^{*}$. The $0.5 \mathrm{~m} \mathrm{~s}^{-1}$ threshold is shown with the vertical line, with $\mathrm{u}^{*}$ values greater than the threshold exhibiting reduced scatter.

photosynthesis are described by Winner and colleagues (2004), transpiration is described by Unsworth and colleagues (2004), and the light environment is described by Parker and coworkers (2004) and Mariscal and colleagues (2004). Together, these studies provide insight into the mechanisms and controls on carbon exchange in an old-growth forest.

\section{Methods}

The 500-year-old Wind River old-growth forest studied is in southwestern Washington, USA, and is composed mainly of Douglas-fir (Pseudotsuga menziesii) and western hemlock (Tsuga heterophylla) (Shaw and others 2004). It represents the end point of several gradients: age, biomass (Harmon and others 2004) and structural complexity (leaf-area index estimates range from 7 to 12 , tallest tree height of $65 \mathrm{~m}$ ), and tree density (Franklin and others 2002; Parker and others 2004; Shaw and others 2004). The site and canopy crane are described more completely by Morell (1994), Shaw and colleagues (2004), and Parker and colleagues (2004).

The climate is strongly seasonal with most precipitation confined to the winter and drought occurring during the summer (Shaw and others 2004). The mean air temperature at the site is $8.7^{\circ} \mathrm{C}$, and the mean precipitation is $2467 \mathrm{~mm} \mathrm{y}^{-1}$. The site of the study is located in the Gifford Pinchot National Forest, in southern Washington (latitude $45^{\circ} 49-13.76$ second, longitude $121^{\circ} 57-$ 06.88 second, elevation $371 \mathrm{~m}$ above sea level).
The slope is $3.5 \%$ from southwest toward the northeast. The predominant wind direction, based on the modal frequency from an annual wind rose, is from the west. The site has its best micrometeorologic fetch to the west, where several kilometers of old-growth forest grows across a gradual slope (see above). Hills to the northwest and to the east could potentially influence our measurements, by creating mean vertical flow and other turbulence features if the wind flows directly over the hills. However, wind-rose data show that the wind flows around the hills, reducing adverse topographic effects. Microclimatic measurements were made at stations at 2, 12, 23, 40,57, and $68 \mathrm{~m}$ above ground level. Further information about the microclimate data is reported by Pyles and colleagues (2000) and Shaw and colleagues (2004).

Our estimates of NEE involved the following general methodology. Data reported here were collected between May 1998 and August 1999. Eddy covariance was assumed to represent an imperfect measurement technique because of limitations at low turbulence levels and because it is only one component in the general mass budget equation for scalar exchange (Paw U and others 2000). The general mass budget equation for NEE for an elemental volume involves much more than turbulent exchange (Paw U and others 2000); after integration in time (half-hour periods usually), the vertical equation becomes:

$$
N E E=F_{h}+F_{v}+F_{e}+S+F_{e u}
$$

where the terms are identified by their associated processes: $S$ is the storage, $F_{h}$ is the mean horizontal advection, $F_{v}$ is the mean vertical advection, $F_{e}$ is the detectable vertical eddy covariance of $\mathrm{CO}_{2}$ measured at $70 \mathrm{~m}$, and $F_{e u}$ is any undetectable vertical eddy covariance of $\mathrm{CO}_{2}$ (because of small turbulent velocities or $\mathrm{CO}_{2}$ perturbations). We assumed that $F_{e u}$ was small and could be neglected. When NEE is reported in this article as carbon mass exchange, it has been converted from the measured or estimated $\mathrm{CO}_{2}$ exchange, $F_{e}$.

We used two types of methods, the first of which assumed all nonnegligible terms were measured or estimated. The second method assumed that the sum $\left(F_{h}+F_{v}\right)$ at low turbulence levels (see below for the $u^{*}$ threshold discussion) could be approximated by a function based on the dependence of $F_{e 3}$ and $F_{e}$ on soil and air temperature, measured during moderate to high turbulence levels, where $F_{e 3}$ is the eddy covariance measured at the $3-\mathrm{m}$ level. The sum $\left(F_{h}+F_{v}\right)$ was assumed to be negligible when the turbulent friction velocity $u^{*}$ was above the threshold discussed below, following 


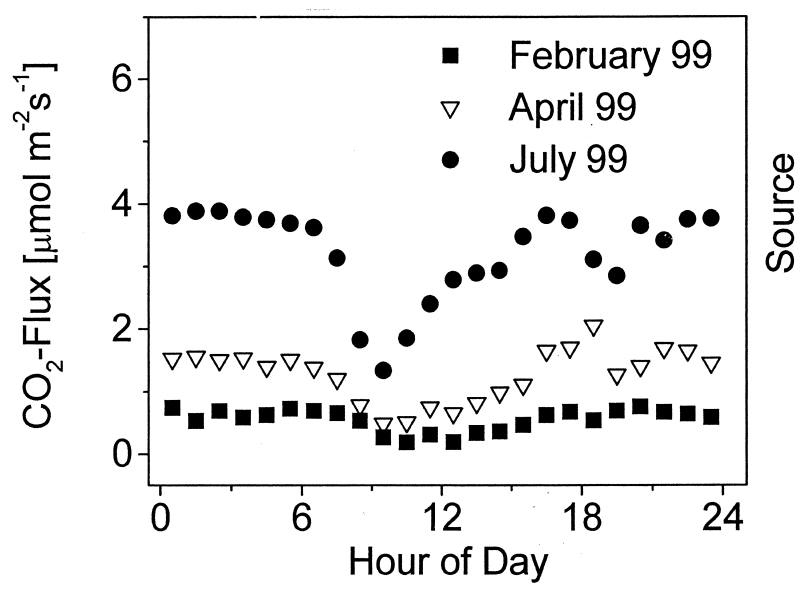

Figure 2. Understory $\mathrm{CO}_{2}$-exchange estimated from the diurnal half-hourly $3 \mathrm{~m}$ eddy-covariance data and including storage estimates. Composite averages for halfhourly values, in February, April and July 1999 are presented.

standard methods in eddy-covariance studies (Black and others 1996; Goulden and others 1996; Falge and others 2001; Pilegaard and others 2001; Barr and others 2002). $S$ was not directly measured and was neglected because it should be approximately zero when integrated over a daily or an annual cycle. However, the storage term is potentially important for hourly and half-hourly analysis of energy budget data (Pyles and others 2000).

Two identical eddy-covariance systems were mounted at $3 \mathrm{~m}(35 \mathrm{~m}$ west of the Wind River canopy crane tower) and at $70 \mathrm{~m}$ (on the tower). Eddy-covariance estimates of vertical water and $\mathrm{CO}_{2}$ fluxes were made using Solent Gill HS 3-D sonic anemometers (Gill Instruments, Lymington, UK) and fast-response Li-Cor 6262 infrared gas analyzers (IRGAs; Li-Cor Biosciences, Lincoln, NE, USA), which measured the velocity vector, sonic temperature, and the concentrations of water and $\mathrm{CO}_{2}$ at $10 \mathrm{~Hz}$. The IRGAs were located close to the sonic anemometer, and heated sample tubes were kept short $(1-5 \mathrm{~m})$ with high flow rates of $10 \mathrm{~L}$ $\mathrm{min}^{-1}$ to minimize signal loss and to keep time lag between vertical velocity and water and $\mathrm{CO}_{2}$, respectively, minimal $(\Delta t=0.5-0.6 \mathrm{~s})$. The lower eddy-covariance system measured understory $(3 \mathrm{~m}$ and below) and soil NEE, and the upper eddy-COvariance system measured NEE for the ecosystem.

The sonic anemometers operate at low rainfall rates, and only at the highest rainfall rates (greater than $4 \mathrm{~mm} \mathrm{~h}^{-1}$ ) were data quality degraded. In addition, power outages and maintenance necessitated replacing missing data periods, the method for which is described below.
All fast-response velocity components and scalars (sonic-derived temperature, water and $\mathrm{CO}_{2}$ concentrations) were logged at $10 \mathrm{~Hz}$, and all raw data were archived. Turbulent statistics, included eddy covariances, were estimated for 0.5-h intervals of the raw data. Covariance exchange data were corrected for spectral drop-off and effects that Webb and colleagues (1980) associated with water-vapor fluctuations [temperature fluctuations were negligible by the time the gas samples reached the IRGA because of the line length and the relatively high thermal conductivity of polytetraflouroethylene (PTFE)]. Both these corrections were small, affecting only a few percent.

A vertical and horizontal advection system for $\mathrm{CO}_{2}$ and water was implemented by constructing a manifold valve system to sample the gas concentrations at 15 points along two horizontal and one vertical, almost perpendicular, axes. The manifold valve system was attached to a single Li-Cor 6262 IRGA, with each of 15 ports sampled every 3 min during a half-hour period. Eight vertical samples were taken at 2, 10, 20,30, 40, 50, 60, and $70 \mathrm{~m}$, and seven additional horizontal samples were taken 50 and $100 \mathrm{~m}$ to the west and $60 \mathrm{~m}$ to the north, at 2 and $30 \mathrm{~m}$ above the ground.

We estimated advection by using data gathered during intensive field campaigns of approximately 2 weeks in April 1999. The horizontal advection term $F_{h}$ was estimated by vertically integrating (to $3 \mathrm{~m}$ ) the product of the half-hour mean horizontal velocity vector and mean horizontal concentration gradient. The mean horizontal velocity and concentration fields were interpolated and extrapolated to the canopy top, from the data taken at 2 and $30 \mathrm{~m}$, and assuming zero horizontal concentration gradient above the canopy, where no carbon source or sinks existed. Similarly, the vertical advection term $F_{v}$ was estimated by vertically integrating from 0 to $60 \mathrm{~m}$ the product of the half-hour mean vertical velocity interpolated throughout the vertical from the 70-m measurement, and the vertical concentration gradients in layers, as measured by the eight vertical sample locations. The tilt of the mean airflow in comparison to the sensor orientation was determined using the two-dimensional plane regression method described by Paw $\mathrm{U}$ and colleagues (2000).

The ratio of the mean horizontal advection and the mean 3-m eddy covariance of $\mathrm{CO}_{2}$ measured during a field campaign was used to define two linked correction factors. The correction factor $(0.21 \pm 0.21)$ was multiplied by the 3 -m eddycovariance data to estimate $F_{h}$ (mean horizontal 


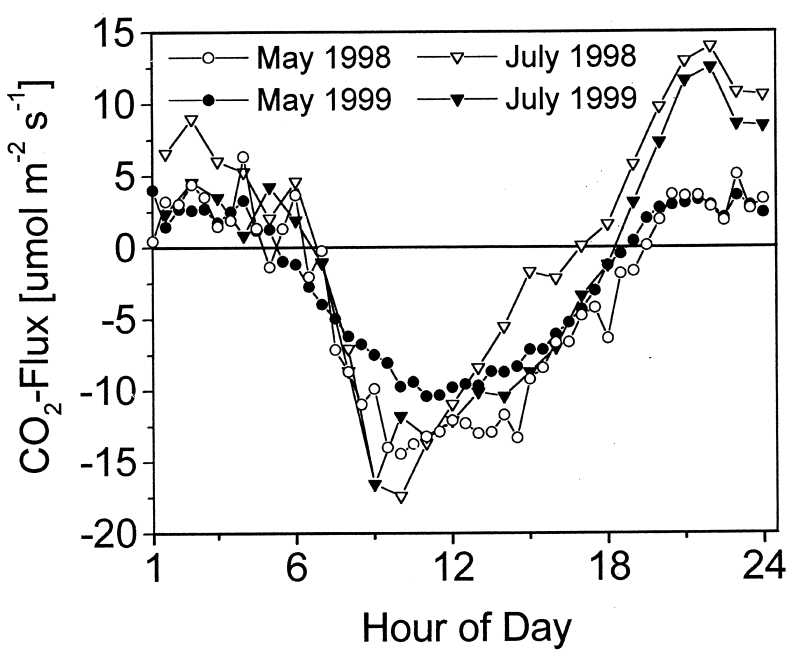

Figure 3. Average diurnal old-growth forest-atmosphere exchange of $\mathrm{CO}_{2}$ for May and July of 1998 and 1999, as measured by eddy-covariance at $70 \mathrm{~m}$, and storage measured by a vertical profile system. July 1998 was during El $\mathrm{Ni}^{*} \mathrm{O}-\mathrm{La} \mathrm{Ni}^{*}$ a transition associated drought period, in contrast to July 1999 when ample soil moisture was available. The night-time temperatures were higher in 1998 than 1999. Positive values represent a source of $\mathrm{CO}_{2}$.

advection). On an annual basis, the $3 \mathrm{~m}$ respiration is approximately 0.7 of the total ecosystem respiration at this site; hence, a second correction factor of 0.3 was used to incorporate aboveground respiration. These values are slightly higher, but consistent with estimates by Thom (1975) of the 0.120.13 fraction of vertical eddy flux that represents horizontal advection. The mean vertical advection $\left(F_{v}\right)$ was negligible on the average, so it was omitted. It was assumed that the correction factor accurately represented the entire year, based on the hypothesis that the mean turbulent Peclet number was well represented during the field campaign. The corrected NEE was estimated as the sum of the eddy-covariance values at $70 \mathrm{~m}$ and estimated $F_{h}$ (the 3-m eddy covariance times the correction factor).

Another widely used correction method was developed for low wind-speed conditions, when the low friction velocity $u^{*}$ was less than $0.25-0.5$ $\mathrm{m} \mathrm{s}^{-1}$ (the threshold was varied to evaluate the effects) indicated that the eddy-covariance sensors may have missed weak signals or that, under low turbulence conditions, advection may dominate. Below $u^{*}$ values of $0.5 \mathrm{~m} \mathrm{~s}^{-1}$, a decreasing overall trend and an increase in scatter were observed for $F_{e 70}$, whereas, above this threshold, $F_{e 70}$ was always positive (Figure 1). Therefore, a threshold of $u^{*}$ less than $0.5 \mathrm{~m} \mathrm{~s}^{-1}$ was chosen for this site. The rela- tionship between $u^{*}$ and nighttime $F_{e}$ did not show any seasonality. This method also involved the assumption that, under moderate to high winds, the sum of $\left(F_{h}+F_{v}+F_{e u}\right)$ could be approximated by a function based on the dependence of $F_{e}$ on air temperature. When the $u^{*}$ was less than the threshold, eddy-covariance data at $70 \mathrm{~m}$ were replaced by ecosystem respiration estimated from the canopy air temperature. Approximately $36 \%$ of all data were replaced for $u^{*}$ less than $0.50 \mathrm{~m} \mathrm{~s}^{-1}$ (the screening criterion was applied only to data gathered at night). A related method was used to replace $F_{e 3}$ data during the day to estimate respiration rather than soil and understory exchange below 3 $\mathrm{m}$ where daytime data was discarded but no $u^{*}$ threshold was applied. An exponential fit against 5 $\mathrm{cm}$-depth soil temperature was made for all nocturnal $F_{e 3}$.

Other missing data [caused by heavy rain, wind directions between $45^{\circ}$ and $135^{\circ}$ (from the easterly direction moving over a hill and through the tower), and power and maintenance outages] were each replaced by calculating a 4-day average from the same half-hour period of neighboring days $(12.7 \%$ of the data; no apparent seasonal trend, monthly fill values varying from $1 \%$ to $29 \%$ ). In the case of rainy days, in general, neighboring days also had high-humidity, cloudy conditions, such that the NEE was expected to be similar.

The two correction methods were relatively independent because the first advection correction method employed $F_{e 3}$ for all times multiplied by the correction factor. In the second method, high wind-speed measurements of $F_{e 3}$ and $F_{e}$ were used to obtain temperature-dependent relationships; then data with $u^{*}$ values less than the threshold were omitted and were replaced with the temperature-based estimates of $F_{e 3}$ and $F_{e}$, for nocturnal time periods. Therefore, somewhat different data sets were used for these corrections.

$F_{e 3}$ did not show any degradation in data quality by stability during nighttime hours. Vertical temperature profiles show a local temperature inversion at the bottom of the canopy, with warm air trapped in the lowest 10-20 $\mathrm{m}$ of the canopy. Spectral analysis shows that turbulence is well formed during nighttime hours. Hence, no $u^{*}$ correction was applied to the $F_{e 3}$ data. However, data clearly show a daytime depression in the $F_{e 3}$, which is exclusively positive, representing continuous respiration into the canopy at the lower boundary. This depression of soil/understory respiration is clearly shown in Figure 2 and represents carbon 


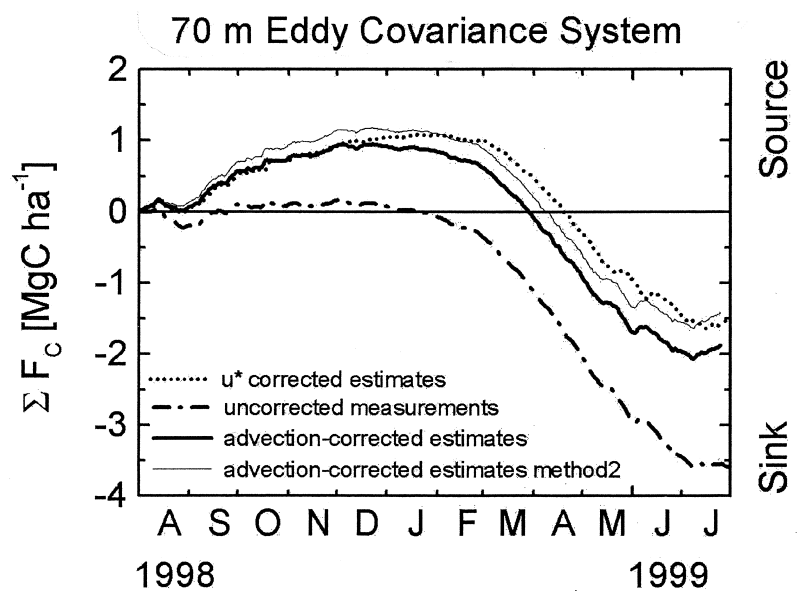

Figure 4. Cumulative carbon exchange as measured by the $70 \mathrm{~m}$ station between July 1998 and the end of July 1999. The dash-dotted line represents uncorrected measurements; the solid line, advection-corrected estimates with a 0.21 correction factor; solid gray line, advectioncorrected with a 0.30 correction factor; and the dotted line, low $\mathrm{u}^{*}\left(\mathrm{u}^{*}<0.5 \mathrm{~m} \mathrm{~s}^{-1}\right)$ corrected estimates.

uptake by photosynthetic activity by the understory vegetation. To get an estimate of soil respiration only, we had to correct the half-hourly data set for this missing amount of carbon by using a nighttime respiration versus temperature model and then replace all daytime data with the modeled results, using this equation:

$$
F_{e 70}=a \exp \left(b T_{a 2}\right)
$$

where $T_{a 2}$ was the 0.5 -h mean air temperature at 2 $\mathrm{m}, a$ is a constant equal to $1.7 \mu \mathrm{mol} \mathrm{m}^{-2} \mathrm{~s}^{-1}$ with a standard deviation of $0.3 \mu \mathrm{mol} \mathrm{m} \mathrm{m}^{-2} \mathrm{~s}^{-1}$, and $\mathrm{b}$ is a constant equal to $0.07^{\circ} \mathrm{C}^{-1}$ with a standard deviation of $0.01{ }^{\circ} \mathrm{C}^{-1}$, and an overall $r^{2}$ of 0.2 . Tower effects on 0.5 hour flux estimates were determined to be less than $5 \%$ for the upwind direction, but potentially higher $(15 \%-30 \%)$ in the rare, downwind direction, based on an experiment where sonic anemometers were mounted upwind and downwind of the tower at $70 \mathrm{~m}$. A footprint model (Wilson and Swaters 1991) indicated the fetch for the $70-\mathrm{m}$ measurements was good (200 m or less) in all directions under unstable (usually daytime) conditions, but was problematic under stable conditions $(1-100 \mathrm{~km})$ due to fragmentation of age classes in the surrounding areas beyond the oldgrowth stand that extended $4 \mathrm{~km}$ toward the west. Preliminary data indicated, however, that eddycovariance respiration fluxes (expected to be high at night) were not sensitive to wind direction, probably because the nocturnal respiration rates for the younger biomes surrounding the old-growth forest were similar to that of the old-growth forest (J. Chen and others 2004), and land cover in the predominant wind directions were forested.

\section{Results AND Discussion}

\section{Net Ecosystem exchange}

The diurnal variation of estimated NEE, averaged over a month, involved maximum uptake of $\mathrm{CO}_{2}$ in the day and net $\mathrm{CO}_{2}$ release at night (Figure 3). Daily maximum uptake rates were on the order of $20 \mu \mathrm{mol} \mathrm{m} \mathrm{m}^{-2} \mathrm{~s}^{-1}$. The diurnal maximum in Figure 3 does not represent the typical clear-sky maximum because it is the average of data from both cloudy and clear days.

Both photosynthesis and respiration decreased during daylight hours when the soil was dry, which limited net ecosystem photosynthesis in July 1998 compared to July 1999, a period with wetter soil conditions. The May data show higher net photosynthesis rates than July, for both years. In general, soil moisture is greater in the spring than later when the seasonal drought starts, allowing for higher net photosynthesis in spring.

Although there were no sustained periods longer than a month when a net sink for carbon did not take place, on a monthly averaged basis some $\mathrm{CO}_{2}$ was released to the atmosphere in July and September of 1998 (Figure 4). July 1998 was a drought period (no precipitation was recorded; data in the lowest quartile of climatological records of 1931-77 for this month), probably associated with the El Niño-La Niña transition (based on Pacific Ocean surface-temperature changes). The low precipitation pattern continued through September, resulting in lower soil moisture levels in 1998 than 1999 (Unsworth and others 2004). For example, in the interval 7-17 September 1998, the volumetric soil moisture averaged 0.106, compared to the same interval in 1999, where the moisture averaged 0.119 (Unsworth and others 2004). Phillips and colleagues (2002) also showed soil moisture levels in August 1998 approximately 10\% drier than in August of 1999. In the more typical climatology of 1999, there were no monthly averages with net release of $\mathrm{CO}_{2}$; precipitation in May 1999 was in the highest quartile of the climatological records, whereas the succeeding 2 months were near the median. The cumulative NEE from the Wind River old-growth forest shows remarkable sequestration of carbon, comparable to many younger forests (Figure 4). The annual integrated carbon uptake (1 August 1998 to 31 July 1999) from the atmosphere by the old-growth forest was estimated using the 


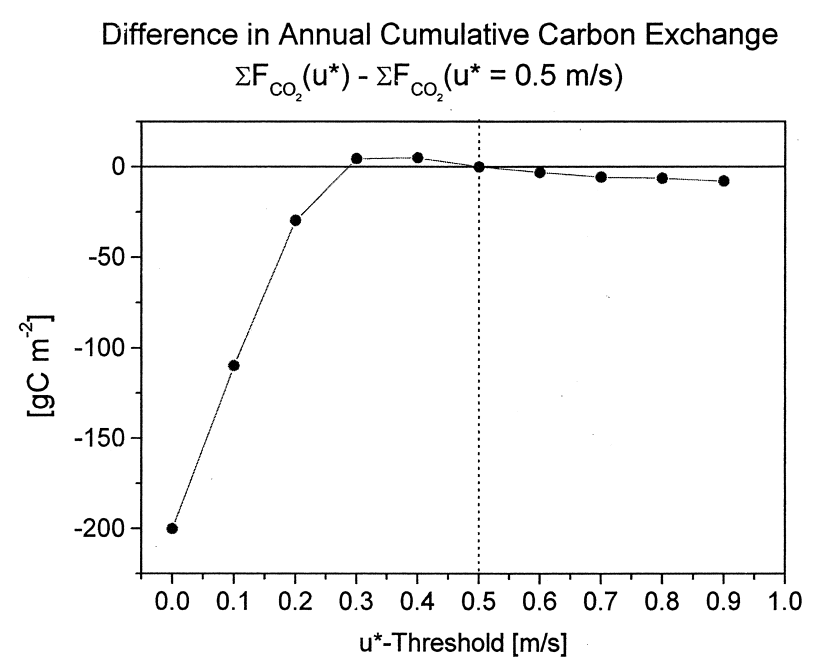

Figure 5. Variation in annual cumulative carbon exchange with $\mathrm{u}^{*}$ threshold.

advection correction (0.21) at $1.9 \mathrm{Mg} \mathrm{C} \mathrm{ha}^{-1} \mathrm{y}^{-1}$ (range, 0.2-3.6 Mg C ha ${ }^{-1} \mathrm{y}^{-1}$ ), estimated using 0.30 advection correction at $1.5 \mathrm{MgC} \mathrm{ha} \mathrm{Mg}^{-1} \mathrm{y}^{-1}$ (range, -0.2 to $3.2 \mathrm{Mg} \mathrm{C}^{-1} \mathrm{y}^{-1}$ ) and estimated using the widely used low $u^{*}$ canopy air-temperature correction method at $1.5 \mathrm{Mg} \mathrm{C} \mathrm{ha} \mathrm{Mg}^{-1} \mathrm{y}^{-1}$ (range, 1.0-1.9 $\mathrm{Mg} \mathrm{C} \mathrm{ha}^{-1} \mathrm{y}^{-1}$ ). Our estimates were relatively insensitive to choice of the $u^{*}$ threshold (see Figure 5). Our values are comparable to the average (1.8 $\left.\mathrm{Mg} \mathrm{C} \mathrm{ha}^{-1} \mathrm{y}^{-1}\right)$ of younger Ameriflux forest sites (40-250 years old; sites are Harvard, Howland, Metolius, Niwot Ridge, Park Falls/WLEF, and Willow Creek) at approximately the same latitude $\left(40^{\circ}-50^{\circ}\right)$ and lower than the average $\left(2.8 \mathrm{Mg} \mathrm{C} \mathrm{ha}^{-1} \mathrm{y}^{-1}\right)$ for younger Fluxnet forests at a wider range of latitudes $\left(2^{\circ}-64^{\circ}\right)$, ranging from 30 to 250 years old, including the AmeriFlux sites identified above and, in addition, Blodgett, Brasschaat, Castelporziano, Duke, Flakaliden, Hesse, Hyytalia, Loobos, Manaus, North Boreas, Norunda, Tharandt, Vielsalm, and Walker Branch. Forest types were temperate coniferous, high-altitude coniferous, boreal coniferous, temperate deciduous, cold-temperate deciduous, Mediterranean evergreen, and tropical rain forest (Falge and others 2002). Results were also slightly lower than the average of $2.2 \mathrm{MgC} \mathrm{ha}^{-1} \mathrm{y}^{-1}$ for the Harvard Forest from 1990 to 1995 (Goulden and others 1996). These results apparently contradict the interpretation of some biomass inventory studies that reported that old-growth forests are not sinks or are only feeble sinks of $\mathrm{CO}_{2}$ [other forest sites: DeBell and Franklin (1987), Franklin and DeBell (1988), Harmon and others (1990), and Schulze and others (1999); our site: Harmon and others (2004)]. These results are compatible with other inventory reports of significant carbon sinks of $1.7-2.9 \mathrm{Mg} \mathrm{C} \mathrm{m}^{-2} \mathrm{y}^{-1}$ in forests from 80 to over 200 years old [(Turner and others 2000) the lower number for the older forests, no specific site] and a similar estimate of $0.8-2.8 \mathrm{Mg} \mathrm{C} \mathrm{m}^{-2} \mathrm{y}^{-1}$ (average, $1.7 \mathrm{Mg} \mathrm{C} \mathrm{m}^{-2} \mathrm{y}^{-1}$ ) for a 450-year-old Douglas-fir forest (Grier and Logan 1977), which may have had less nutrient limitations than the Wind River old-growth forest. Also, a statistical survey of young, mature, and oldgrowth Douglas-fir stands in the Cascade Mountains found increasing basal area and woody-debris volume between the mature and old-growth age classes (Spies and Franklin 1991), which also suggests a carbon sink in older stands. Differences between mature forests and old-growth forests are often confused. Our definition is adopted from that of Franklin and colleagues (2002), which considers that mature forests are composed of large live trees of near full height and a closed canopy. In contrast, the structure of an old-growth forest differs from a mature forest in the complexity of its vertical and horizontal structure, the presence of shade-tolerant species in the upper canopy, trees of all age classes, presence of canopy gaps, standing snags, large woody debris, and more complex structured soil.

The large ranges of plausible values associated with both the biomass inventory (noted below) and the micrometeorologic estimates (discussed above) imply that the micrometeorologic and biometric inventory results are in reasonable agreement (Anthoni and others 1999; Field and Kaduk 2004). Biomass estimation methods reflect a much longer time integration and therefore could differ from an annual measurement. Biomass estimates may have a wide range of possible errors, not all of which can be easily quantified by statistical analysis if the sources of errors are not well understood. This is reflected in a wide range of estimation values in the literature for various inventory components at other sites (Santantonio and others 1977; Keyes and Grier 1981; Santantonio and Hermann 1985; Steele and others 1997; Ehman and others 2002; Malhi and others 1999; Clark and others 2001). Micrometeorologic methods also have potentially large errors, as indicated earlier in this report. Thus, the results reported by Harmon and colleagues (2004) and ours agree within the range of errors of the two methods.

The ecosystem net $\mathrm{CO}_{2}$ exchange saturates at PAR intensities above $1000 \mu \mathrm{mol} \mathrm{m} \mathrm{m}^{-2} \mathrm{~s}^{-1}$ (Figure 6). Parker and colleagues (2004) and Mariscal and colleagues (2004) show that the canopy above $30-\mathrm{m}$ height routinely receives sufficient light for photosynthetic saturation. The apparent ecosystem 


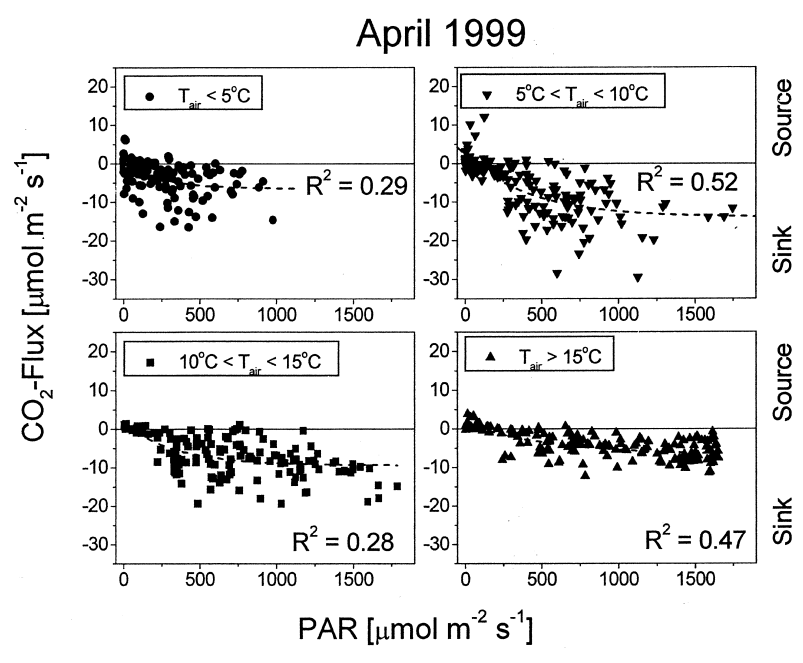

Figure 6. Half-hourly exchange of $70 \mathrm{~m}$ eddy-covariance $\mathrm{CO}_{2}$-exchange, plotted as a function of above-canopy PAR, and mean air temperature at $70 \mathrm{~m}$, in April 1999.

compensation point (zero $\mathrm{CO}_{2}$ flux) was approximately $50 \mu \mathrm{mol} \mathrm{m} \mathrm{m}^{-2} \mathrm{~s}^{-1}$, well within the range of several closed canopy forests described by Ruimy and colleagues (1995). On-site leaf-based chamber measurements for $P$. menziesii and T. heterophylla show a similar saturation at $500-1200 \mu \mathrm{mol} \mathrm{m}{ }^{-2} \mathrm{~s}^{-1}$ (Winner and others 2004). An optimum temperature range of $5^{\circ}-10^{\circ} \mathrm{C}$ was found in April 1999 , which coincides with the mean April air temperature of $6.4^{\circ} \mathrm{C}$, the mean April radiative surface temperature of $7.1^{\circ} \mathrm{C}$ (approximately the tissue temperature), and the mean annual temperature of the region $\left(8.7^{\circ} \mathrm{C}\right.$ for the nearby Carson Fish Hatchery station, averaged between 1978 and 1998). During April 1999, vapor-pressure deficit values were low, and no discernible control of water stress on net $\mathrm{CO}_{2}$ exchange could be determined.

\section{Soil Respiration and Understory Flux}

The 3-m eddy fluxes show a $Q_{10}$ relationship (2.0 for minimum temperature; $r^{2}=0.61$ ) between the integrated daily soil and understory respiration and 5-cm-depth soil temperature (Figure 7). The curves are very similar to the canopy respiration estimates reported by Greco and Baldocchi (1996). Interestingly, there appeared to be soil respiration even for slightly subzero temperatures in the soil. This can be interpreted that the deeper layers of the soil were sufficiently warm for continued respiration, or that free water was available possibly because of freezing-point depression.

Preliminary soil chamber measurements (from measurements taken during a few hours a day per month) in May and July 1999 yielded soil efflux rates ranging from 3.9 to $5.0 \mu \mathrm{mol} \mathrm{m} \mathrm{m}^{-2} \mathrm{~s}^{-1}$ (J. Klopatek personal communication) compared to the monthly mean 3-m eddy-covariance rates (corrected for advection and photosynthesis) of $2.2-4.2 \mu \mathrm{mol} \mathrm{m} \mathrm{m}^{-2} \mathrm{~s}^{-1}$. For the weeks in which the chamber measurements were taken, the soil temperature-based estimates from the model increased from 1.9 to $4.8 \mu \mathrm{mol} \mathrm{m} \mathrm{m}^{-2} \mathrm{~s}^{-1}$. Chamber and micrometeorologic measurements for gases such as $\mathrm{CO}_{2}$ and water vapor may differ from eddy-covariance measurements. Concurrent eddy-flux measurements range from greater than chamber measurements, near equality between the two, and greatly below chamber measurements by more than $80 \%$ (Dugas and others 1991; Norman and others 1997; Law and others 1999; Janssen and others 2000, 2001; Anderson and Farrar 2001).

The flux measured with the 3-m eddy-covariance system represents soil efflux and understory exchange, including understory photosynthetic uptake of $\mathrm{CO}_{2}$. On a diurnal basis, we can identify the contribution of the uptake by vegetation, as shown by a depression in the efflux during the middle of the day (Figure 2) during spring and summer. The flux never becomes negative; that is, the soil respiration is sufficiently strong that the understory vegetation cannot photosynthesize all respired carbon under $3 \mathrm{~m}$, resulting in typical values of over $2.5 \mu \mathrm{mol} \mathrm{m} \mathrm{m}^{-2} \mathrm{~s}^{-1}$ for July 1999. In April 1999, the midday depression is still clearly visible even though its magnitude and the overall efflux have been reduced due to lower light and temperature levels. For the winter, the diurnal course is almost flat, greatly reduced to values around or below $1 \mu \mathrm{mol} \mathrm{m} \mathrm{m}^{-2} \mathrm{~s}^{-1}$, but still positive with only a very small depression during the day as shown for February 1999.

The averaged monthly values of the 3-m eddycovariance $\mathrm{CO}_{2}$ flux steadily declined from 3$4 \mu \mathrm{mol} \mathrm{m}{ }^{-2} \mathrm{~s}^{-1}$ in the summer down to $1 \mu \mathrm{mol} \mathrm{m}{ }^{-2}$ $\mathrm{s}^{-1}$ in December 1998 as the soil temperature dropped (Figure 3). In the summer of 1998, the site experienced a 78-day drought in connection with the 1997-98 El Niño event, such that the associated water stress reduced understory carbon uptake. The effects of precipitation dominate carbon exchange (Nemani and others 2002). A difference between the 2 years is apparent (Figure 3) probably as a result of elevated soil respiration in 1998 compared to 1999, related to temperature effects (mean July 1998 5-cm-soil temperature $18.0^{\circ} \mathrm{C}$; mean July 1999 soil temperature $15.5^{\circ} \mathrm{C}$ ). Overall, the forest was a source of carbon for the summer of 1998 due to the dominance of respiration. 


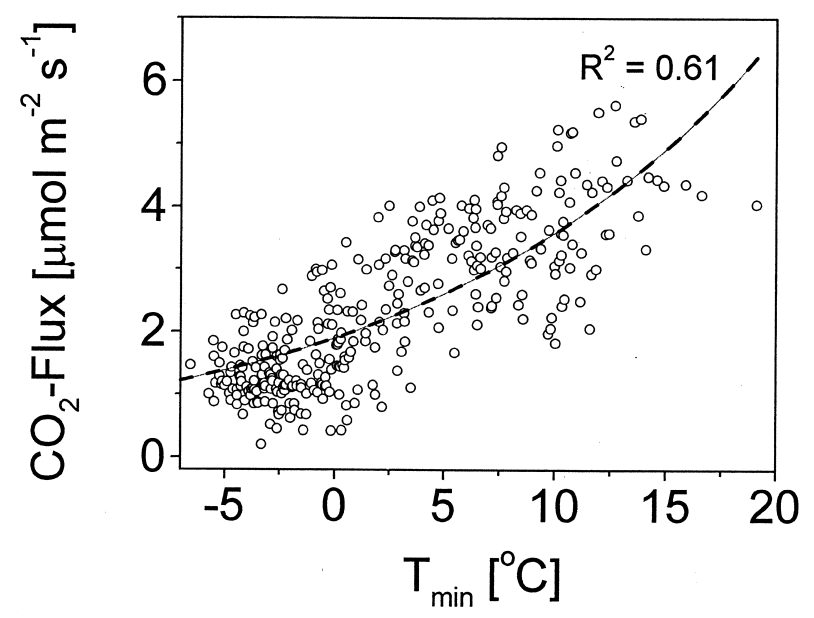

Figure 7. Effect of air temperature (minimum air temperature at $2 \mathrm{~m}$ ) on nocturnal respiration as measured by 3 m eddy covariance.

The late winter-early spring (March to MayJune 1999) was the period of the greatest NEE uptake as measured by the 70-m eddy-covariance system (Figure 4). The relatively low soil respiration coupled with very active photosynthesis by the canopy enabled the ecosystem to take up significant amounts of carbon. During 1999, a cool and wet summer (La Niña 1998-99), the stand acted as a sink for carbon despite the elevated respiration term. The figure also shows that, contrary to the slow decline in the 3-m $\mathrm{CO}_{2}$ eddy flux for the fall, the rise in the spring takes place rather rapidly, jumping from $1 \mu \mathrm{mol} \mathrm{m}{ }^{-2} \mathrm{~s}^{-1}$ in April to $3 \mu \mathrm{mol}$ $\mathrm{m}^{-2} \mathrm{~s}^{-1}$ in June 1999.

The respiratory exchange from the forest understory (measured at the 3-m height), including advection and photosynthetic correction, was 10.9 Mg C ha $\mathrm{Mg}^{-1} \mathrm{y}^{-1}\left(9.0-12.8 \mathrm{Mg} \mathrm{C} \mathrm{ha}^{-1} \mathrm{y}^{-1}\right)$, and the annual ecosystem respiration based on canopy air temperature and nocturnal 70-m eddy-covariance data was $14.0 \mathrm{Mg} \mathrm{C} \mathrm{ha}^{-1} \mathrm{y}^{-1}$. This yields a gross ecosystem production of approximately 15.515.9 Mg C ha-1 $\mathrm{y}^{-1}$, which is greater than the 10.213.5 Mg C ha ${ }^{-1} \mathrm{y}^{-1}$ estimated for midlatitude mixed deciduous forests, boreal forests, and Euroflux forests at approximately the same latitude (Wofsy and others 1993; Black and others 1996; Goulden and others 1996; Schmid and others 2000; Valentini and others 2000), but less than the biometric estimates of gross primary production $\left(21.0 \mathrm{Mg} \mathrm{C} \mathrm{ha}^{-1} \mathrm{y}^{-1}\right)$ reported by Harmon and colleagues (2004).

Total ecosystem respiration can be estimated using the temperature model for nighttime $\mathrm{Fe}_{70}$ for hours with $u^{*}$ greater than $0.5 \mathrm{~m} / \mathrm{s}$ and running it for all hours of the year. Subtraction of the annual sum of the 3-m eddy-covariance data corrected for photosynthesis of the understory from the annual total ecosystem respiration estimate yielded an estimate of $3.1 \mathrm{MgC} \mathrm{ha}^{-1} \mathrm{y}^{-1}$. This value is an approximation for aboveground respiration from the living and dead biomass based on eddy-covariance data and derived temperature models only, and it is lower than the biometric estimates (Harmon and others 2004). It should be emphasized that this estimate was not used in computing NEE.

\section{Conclusions}

In contrast to frequently stated opinions, oldgrowth forests can be significant carbon sinks. Our eddy-flux estimates of NEE for the 16-month period show net carbon gain for the period and are within the error estimates derived independently from inventory data by Harmon and colleagues (2004) that integrate data over a much longer period and are based on data measured from a wide range of sites. The old-growth forest at the Wind River canopy crane site retains the capacity to sequester significant amounts of carbon on an annual basis. For the period reported here, the annual rate varied between years consistent with the interannual difference in weather. In the year with higherthan-average rainfall, carbon sequestration was at or near the values of other forests, including younger forests and deciduous broadleaf forests. The mild winters permit carbon sequestration throughout the winter, and there were no extended periods of dormancy, which contributed to the high annual rate of carbon uptake. The low light compensation point, penetration of diffuse light deep into the canopy, and the cool temperature optimum of photosynthesis contribute to net carbon sequestration during winter. The highest rates of carbon uptake occur in spring. The length and severity of the summer drought appear to control the magnitude and timing of the switch from a carbon sink to a carbon source. The oldgrowth forests of the Pacific Northwest can contribute to optimizing carbon sequestration strategies while continuing to provide ecosystem services essential to supporting biodiversity.

\section{ACKNOWLEDGEMENTS}

We thank Trevor Newton, Matt Schroeder, Jessica Wade-Murphy, Shane Motley, Sonia Wharton, Liyi Xu, and Drs. Dave Shaw, Xinli Wang, Bryan Weare, Richard Grotjahn, and Jerry Franklin for their help in carrying out this research, and Drs. 
Michael Unsworth, David Turner, Michael Ryan, Mark Harmon, and Chris Field for their comments regarding early drafts of this report. This research was supported by the Office of Science, Biological and Environmental Research Program (BER), US Department of Energy (DOE), through the Western Regional Center (WESTGEC) of the National Institute for Global Environmental Change (NIGEC) under Cooperative Agreement DE-FC03-90 ER61010. J. Wade-Murphy was supported by the US Department of Energy Global Change Education Program. The Wind River Canopy Crane Research Facility is operated under joint sponsorship of the University of Washington and the USDA Forest Service/Pacific Northwest Station, and we acknowledge both for significant support. Any opinions, findings, and conclusions or recommendations expressed herein are those of the authors and do not necessarily reflect the view of the DOE.

\section{REFERENCES}

Anderson DE, Farrar CD. 2001. Eddy covariance measurement of $\mathrm{CO}_{2}$ flux to the atmosphere from an area of high volcanogenic emissions, Mammoth Mountain, California. Chem Geol 177:31-42.

Anthoni PM, Law BE, Unsworth MH. 1999. Carbon and water vapor exchange of an open-canopied ponderosa pine ecosystem. Agric For Meteorol 95:151-68.

Baldocchi D, Finnigan J, Wilson K, Paw U KT, Falge E. 2000. On measuring net ecosystem carbon exchange over tall vegetation in complex terrain. Boundary-layer Meteorol 96:25791.

Banuri T, Barker T, Bashmakov I, Blok K, Christensen J, Davidson O, Grubb M, Halsnaes K, Jepma C, Jochem E, Kauppi P, Krankina O, Krupnick A, Kuijpers L, Kverndokk S, Markandya A, Metz B, Moomaw WR, Moreira JR, Morita T, Pan J, Price L, Richels R, Robinson J, Sathaye J, Swart R, Tanaka K, Taniguichi T, Toth F, Taylor T, Weyant J. 2001. Technical Summary. Climate Change 2001: Mitigation. A report of Working Group III of the Intergovernmental Panel on Climate Change. IPCC Secretariat, c/o World Meteorological Organization, Geneva, Switzerland p 43.

Barr AG, Griffis TJ, Black TA, Lee X, Staebler RM, Fuentes JD, Chen Z, Morgenstern K. 2002. Comparing the carbon budgets of boreal and temperate deciduous forest stands. Can J For Res 32:813-22.

Battle M, Bender ML, Tans PP, White JWC, Ellis JT, Conway T, Francey RJ. 2000. Global carbon sinks and their variability inferred from atmospheric $\mathrm{O}_{2}$ and $\delta^{13} \mathrm{C}$. Science 287:2467-70.

Birdsey RA, Planting AJ, Heath LS. 1993. Past and prospective carbon storage in United States Forests. For Ecol Manage 58:33-40

Black TA, Den Hartog G, Neumann HH, Blanken PD, Yang PC, Russell C, Nesic Z, Lee X, Chen SG, Staebler R, Novak MD. 1996. Annual cycles of water vapour and carbon dioxide fluxes in and above a boreal aspen forest. Global Change Biol $2: 219-29$
Carey EV, Sala A, Keane R, Callaway RM. 2001. Are old forests underestimated as global carbon sinks? Global Change Biol 7:339-44.

Chen J, Paw UKT, Ustin SL, Suchanek TH, Wang X, Falk M, Brosofske K, Bi R, King TS. 2004. Net ecosystem exchanges (NEE) of carbon, water and energy in young and old-growth Douglas fir forests. Ecosystems 7:534-44.

Clark DA, Brown S, Kicklighter DW, Chambers JQ, Thomlinson JR, Ni J. 2001. Measuring net primary production in forests: concepts and field methods. Ecol Appl 11:356-70.

DeBell DS, Franklin JS. 1987. Old-Growth Douglas-fir and western hemlock: a 36-year record of growth and mortality. West J Appl For 2:111-4.

DeLucia EH, Hamilton JG, Naidu SL, Thomas RB, Andres JA, Finzi A, Lavigne M, Matamala R, Mohan JE, Hendrey GR, Schlesinger WH. 1999. Net primary production of a forest ecosystem with experimental $\mathrm{CO}_{2}$ enrichment. Science 284:1177-9.

Dugas WA, Fritschen LJ, Gay LW, Held AA, Matthias AD, Reicosky DC, Steduto P, Steiner JL. 1991. Bowen ratio, eddy correlation, and portable chamber measurements of sensible and latent heat flux over irrigated spring wheat. Agric For Meteorol 56:1-20.

Ehman JL, Schmid HP, Grimmond CSB, Randolph JC, Hanson PJ, Wayson CA, Cropley FD. 2002. An initial intercomparison of micrometeorological and ecological inventory estimates of carbon exchange in a mid-latitude deciduous forest. Global Change Biol 8:575-589.

Falge E, Baldocchi D, Olson R, Anthoni P, Aubinet M, Bernhofer C, Burba G, Clement R, Dolman H, Granier A. 2001. Gap filling strategies for defensible annual sums of net ecosystem exchange. Agric For Meteorol 107:43-69.

Falge E, Baldocchi D, Tenhunen J, Aubinet M, Bakwin P, Berbigier P, Bernhofer C, Burba G, Clement R, Davis K. 2002. Seasonality of ecosystem respiration and gross primary production as derived from Fluxnet measurements. Agric For Meteorol 113:53-74.

Fan S, Gloor M, Mahlman J, Pacala S, Sarmiento J, Takahashi T, Tans P. 1998. A large terrestrial carbon sink in North America implied by atmospheric and oceanic carbon dioxide data and models. Science 282:442-6.

Field CB, Kaduk J. 2004. The carbon balance of an old-growth forest: building across approaches. Ecosystems 7:525-33.

Franklin JF. 1988. Pacific Northwest Forests. In: Barbour MG, Billings WD, editors. North American terrestrial vegetation. New York: Cambridge University Press p 104-31.

Franklin JF, DeBell DS. 1988. Thirty-six years of tree population change in an old-growth Pseudotsuga-Tsuga forest. Can J For Res 18:633-9.

Franklin JF, Spies TA, Van Pelt R, Carey AB, Thornburgh DA, Gerg DR, Lindemayer DB, Harmon ME, Keeton WS, Shaw DC. 2002. Disturbances and structural development of natural forest ecosystems with silvicultural implications, using Douglas-fir forests as an example. For Ecol Manage 155:399423.

Goodale CL, Apps MJ, Birdsey RA, Field CB, Heath LS, Houghton RA, Jenkins JC, Kohlmaier GH, Kurz W, Liu SR. 2002. Forest carbon sinks in the Northern Hemisphere. Ecol Appl 12:891-9.

Goulden ML, Munger JW, Fan S-M, Daube BC, Wofsy SC. 1996. Exchange of carbon dioxide by a deciduous forest: response to interannual climate variability. Science 271:1576-78. 
Greco S, Baldocchi DD. 1996. Seasonal variations of $\mathrm{CO}_{2}$ and water vapour exchange rates over a temperate deciduous forest. Global Change Biol 2:183-97.

Grier CC, Logan RS. 1977. Old-growth Pseudotsuga menziesii communities of a western Oregon watershed: biomass distribution and production budgets. Ecol Monogr 47:373-400.

Harmon ME, Bible K, Ryan MG, Shaw DC, Chen H, Klopatek J, Li X. 2004. Production, respiration, and overall carbon balance in an old-growth Pseudotsuga-Tsuga forest ecosystem. Ecosystems 7:498-512.

Harmon ME, Ferrell WK, Franklin JF. 1990. Effects of carbon storage of conversion of old-growth forests to young forests. Science 247:699-701.

Heath LS, Birdsey RA. 1993. Carbon trends of productive temperate forests of the coterminous United States. Water Air Soil Pollut 70:279-93.

Houghton RA, Hobbie JE, Melillo JM, Moore B, Peterson BJ, Shaver GR, Woodwell GM. 1983. Changes in the carbon content of terrestrial biota and soils between 1860 and 1980: a net release of $\mathrm{CO}_{2}$ to the atmosphere. Ecol Monogr 53:235-62.

Janisch JE, Harmon ME. 2002. Successional changes in live and dead wood carbon stores: implications for net ecosystem productivity. Tree Physiol 22:77-89.

Janssen IA, Kowalski AS, Ceulemans R. 2001. Forest floor $\mathrm{CO}_{2}$ fluxes estimated by eddy covariance and chamber-based model. Agric For Meteorol 106:61-9.

Janssen IA, Kowalski AS, Longdoz B, Ceulemans R. 2000. Assessing forest soil $\mathrm{CO}_{2}$ efflux: an in situ comparison of four techniques. Tree Physiol 20:23-32.

Keyes MR, Grier CC. 1981. Above- and below-ground net production in 40-year-old Douglas-fir stands on low and high productivity sites. Can J For Res 1 1:599-605.

Law BE, Baldocchi DD, Anthoni PM. 1999. Below-canopy and soil $\mathrm{CO}_{2}$ fluxes in a ponderosa pine forest. Agric For Meteorol 94:171-88.

Lee X. 1998. On micrometeorological observations of surface-air exchange over tall vegetation. Agric For Meteorol 91:39-50.

Malhi Y, Baldocchi DD, Jarvis PG. 1999. The carbon balance of tropical, temperate and boreal forests. Plant Cell Environ 22:715-40.

Mariscal MJ, Martens SN, Ustin SL, Chen J, Weiss SB, Roberts DA. 2004. Light-transmission profiles in an old-growth forest canopy: simulations of photosynthetically active radiation by using spatially explicit radiative transfer models. Ecosystems 7:454-67.

Melillo JM, Hall DO, Ågren GI. 1996. Executive summary. In: Breymeyer AI, Hall DO, Melillo JM, Å gren GI, editors. Global change: effects on coniferous forests and grasslands. New York: Wiley p 1-16.

Morrell V. 1994. Crane experiment finally perches in Washington State. Science 264:1842 .

Nemani R, White M, Thornton P, Nishida K, Reddy S, Jenkins J. 2002. Recent trends in hydrologic balance have enhanced the terrestrial carbon sink in the United States. Geophys Res Lett 29:106-11064.

Norman JM, Kucharik CJ, Gower ST, Baldocchi DD, Crill PM, Rayment M, Savage K, Striegl RG. 1997. A comparison of six methods for measuring soil-surface carbon dioxide fluxes. $\mathrm{J}$ Geophys Res 102:(28)771-7.

Odum EP. 1963. Ecology. New York: Hold, Rinehart and Winston.

Odum EP. 1965. Fundamentals of Ecology, 2nd ed. Philadelphia: Saunders.
Pacala SW, Hurtt GC, Baker D, Peylin P, Houghton RA, Birdsey RA, Heath L, Sundquist ET, Stallard RF, Ciais P. 2001. Consistent land and atmosphere based U.S. carbon sink estimates. Science 292:2316-20.

Parker GG, Harmon ME, Lefsky MA, Chen J, Van Pelt R, Weiss SB, Thomas SC, Winner WE, Shaw DC, Franklin JF. 2004. Three-dimensional structure of an old-growth PseudotsugaTsuga forest and its implications for radiation balance, microclimate, and atmospheric gas exchange. Ecosystems 7:440-53.

Paw U KT, Baldocchi DD, Meyers TP, Wilson K. 2000. Correction of eddy-covariance measurements incorporating both advective effects and density fluxes. Boundary-layer Meteorol 97:487-511.

Phillips N, Bond BJ, McDowell NG, Ryan MG. 2002. Canopy and hydraulic conductance in young, mature and old Douglas-fir trees. Tree Physiol 22:205-11.

Pilegaard K, Hummelshoj P, Jensen NO, Chen Z. 2001. Two years of continuous $\mathrm{CO}_{2}$ eddy-flux measurements over a Danish beech forest. Agric For Meteorol 107:29-41.

Post WM, Izaurralde RC, Mann LK, Bliss N. 1999. Monitoring and verifying soil organic carbon sequestration. In: Rosenberg NJ, Izaurralde RC, Malone EM, editors. Carbon sequestration in soils. Columbus $(\mathrm{OH})$ : Battelle p 41-66.

Pyles RD, Weare BC, Paw U KT. 2000. The UCD advancedcanopy-atmosphere-soil algorithm (ACASA): comparisons with observations from different climate and vegetation regimes. Q J R Meteorol Soc 126:2951-80.

Ruimy A, Jarvis PG, Baldocchi DD, Saugier B. 1995. $\mathrm{CO}_{2}$ fluxes over plant canopies and solar radiation: a review. Adv Ecol Res 26:1-68.

Santantonio D, Hermann RK. 1985. Standing crop, production, and turnover of fine roots on dry, moderate, and wet sites of mature Douglas-fir in western Oregon. Ann Sci For 42:113-42.

Santantonio D, Hermann RK, Overton WS. 1977. Root biomass studies in forest ecosystems. Pedobiologia 17:1-31.

Schimel DS. 1995. Terrestrial ecosystems and the carbon cycle. Global Change Biol 1:77-91.

Schimel D, Alves D, Enting I, Heimann M, Joos F, Raynaud D, Wigley T, Prather M, Derwent R, Ehhalt D. 1996. Radiative forcing of climate change. In: Houghton JT, Meira Filho LG, Calendar BA, Harris N, Kattenberg A, Maskell K, editors. Climate change 1995: the science of climate change. Cambridge: Cambridge University Press p 65-132.

Schimel DS, Melillo J, Tian H, McGuire AD, Kicklighter D, Kittel T, Rosenbloom N, Running S, Thornton P, Ojima D. 2000. Contribution of increasing $\mathrm{CO}_{2}$ and climate to carbon storage by ecosystems in the United States. Science 287:2004-6.

Schmid HP, Grimmond CSB, Cropley F, Offerle B, Su H-B. 2000. Measurements of $\mathrm{CO}_{2}$ and energy fluxes over a mixed hardwood forest in the mid-western United States. Agric For Meteorol 103:357-74.

Schulze E-D, Lloyd J, Kelliher FM, Wirth C, Rebmann C, Luhker B, Mund M, Knohl A, Milyuokova IM, Schulze W. 1999. Productivity of forests in the Eurosiberian boreal region and their potential to act as a carbon sink: a synthesis. Global Change Biol 5:703-22.

Shaw DC, Franklin JF, Klopatek J, Freeman E, Bible K, Newton T, Greene S, Wade-Murphy J. 2004. Ecological setting of the Wind River old-growth forest. Ecosystems 7:427-39.

Spies TA, Franklin JF. 1991. The structure of natural young, mature, and old-growth Douglas-fir forests in Oregon and Washington. In: Ruggiero LF, Aubry KB, Carey AB, Huff MH, 
technical coordinators. Wildlife and vegetation in unmanaged Douglas-fir forests. General Technical Report PNW-6TR-285. Portland (OR): USDA Forest Service, Pacific Northwest Research Station. p 91-109.

Steele SJ, Gower ST, Vogel JG, Norman JM. 1997. Root mass, net primary production and turnover in aspen, jack pine and black spruce forests in Saskatchewan and Manitoba, Canada. Tree Physiol 17:577-87.

Thom AS. 1975. Momentum, mass and heat exchange of plant communities. In: Monteith JL, editor. Vegetation and the atmosphere. Volume 1. Principles. New York: Academic p 57109.

Turner DP, Cohen WB, Kennedy RE. 2000. Alternative spatial resolutions and estimation of carbon flux over a managed forest landscape in western Oregon. Landscape Ecol 15:44152.

Turner DP, Koerper GJ, Harmon ME, Lee JJ. 1995. Carbon sequestration by forests of the United States: current status and projections to the year 2040. Tellus [B] 47:232-9.

Unsworth MH, Phillips N, Link T, Bond BJ, Falk M, Harmon ME, Hinckley TM, Marks D, Paw U KT. 2004. Components and controls of water flux in an old-growth Douglas-fir-western hemlock ecosystem. Ecosystems 7:468-81.

Valentini R, Matteucci G, Dolman AJ, Schulze E-D, Rebmann C, Moors EJ, Granier A, Gross P, Jensen NO, Pilegaard K. 2000. Respiration as the main determinant of carbon balance in European forests. Nature 404:861-5.

Webb EK, Pearman GI, Leuning R. 1980. Correction of flux measurements for density effects due to heat and water vapour transfer. Q J R Meteorol Soc 106:85-100.

Wilson JD, Swaters GE. 1991. The source area influencing a measurement in the planetary boundary layer: the "footprint" and the "distribution of contact distance." Boundarylayer Meteorol 55:25-46.

Winner WE, Thomas SC, Berry JA, Bond BJ, Cooper CE, Hinckley TM, Ehleringer JR, Fessenden JE, Lamb B, McCarthy S. 2004. Canopy carbon gain and water use: analysis of oldgrowth conifers in the Pacific Northwest. Ecosystems 7:48297.

Wofsy SC, Goulden ML, Munger JW, Fan S-M, Bakwin PS, Daube BC, Bassow SL, Bazzaz FA. 1993. Net exchange of $\mathrm{CO}_{2}$ in a mid-latitude forest. Science 260:1314-7. 